\begin{tabular}{|c|c|c|}
\hline $\begin{array}{l}\text { Editorial \& Publishing Offices : } \\
\text { MACMILLAN \& Co., LTD. } \\
\text { ST. MARTIN's STREET } \\
\text { LONDON, W.C.2 }\end{array}$ & 8 & $\begin{array}{l}\text { Telegraphic Address: } \\
\text { Prosis, Lespuare, Lowdow } \\
\text { Telephone Number: } \\
\text { Whrteralz 883t }\end{array}$ \\
\hline Vol. 144 & SATURDAY, JULY 8, I939 & No. 3636 \\
\hline
\end{tabular}

\title{
SCIENCE IN MODERN AGRICULTURE
}

$\mathrm{I}^{\mathrm{T}}$ is now twenty-nine years since the great forward step was taken which for the first time made agricultural research on any important scale possible in Great Britain. In $1910 \mathrm{Mr}$. Lloyd George set up the Development Commission, charged with the duty of developing agriculture and provided with an endowment fund which avoided the necessity of asking Parliament for money each year: it was thus able to take long views and to carry out important work which might otherwise have been impossible.

The wisdom of this method has been fully justified by the events of the succeeding years, and the twenty-eighth report of this Commission* now issued shows a remarkable range of activities, and a gratifying number of successful achievements of which all concerned may well be proud. The magnitude of the operations may be judged from the fact that the expenditure during 1937-38 amounted in all to $£ 740,466$, as compared with $£ 641,126$ in 1935-36. Of this sum $£ 131,555$ was devoted to fisheries, $£ 2,300$ to land reclamation, and $£ 606,611$ to agricultural and rural industries.

About $£ 500,000$ was in 1937-38 expended under the heading "research", the largest single item being the purchase of an estate at Compton for the provision of facilities for experiments, by the research institutes on livestock, which at present are difficult to carry out. The estate comprises 1,500 acres of easily farmed land on a chalk subsoil, and the herds include nearly 400 pedigree cattle and 450 pedigree pigs. The total price paid for land, buildings, equipment and livestock was $\mathfrak{£ 7 4 , 9 9 5}$. Nearly another $£ 40,000$ is to be expended on further developments.

* Development Commission. Twenty-eighth Report of the Develop. ment Commissioners being for the Year ended the 31st Ifarch 1938 . 'p. 184. (London: H.Jr. Stationery Oflice, 1939.) 38. net.
A full account of the work on foot-and-mouth disease is given. This is one of the most serious and costly troubles in modern agriculture, and at present the only method known of dealing with it is to slaughter at once all infected animals. Slaughter is now compulsory ; but of course compensation has to be paid to the owners, and the cost is very high. Successive ministries have ordered inquiries and carried out some investigations, and since 1924 a sum of about $£ 200,000$ has been spent on this side alone. In these circumstances, it is really distressing to read that until recently the study of the disease was only on a temporary basis: that "changes in the temporary scientific staff employed-changes due, in part at least, to the resignation of young workers seeking more permanent employment than could be offered by a committee constituted for a temporary inquiry-not only made the work very costly, but created something of a 'hope deferred' complex in those, including the commissioners themselves, who were responsible for expenditure". This happened, not as one might think, two hundred years ago, but in 1933 ! One wonders what is the use of our costly educational system that produces a community in which such complete disregard of the need for scientific investigation is possible. Happily this particular difficulty is now overcome and the investigation is to be put on a permanent basis.

A large part of the Commissioners' expenditure is on the agricultural research institutes at Rotham. sted, Cambridge, Oxford, Aberystwyth, Aberdeen, Edinburgh, East Malling, Shinfield and other centres where the different branches of agriculture are shared out, each institute being responsible for a particular set of subjects. The arrangement works 
well, and the cordial relations between the staffs of the institutes on one hand, and the Development Commission, the Agricultural Research Council and the Ministry of Agriculture officials on the other, ensure adequate treatment of all the subjects. The general rule is that the Commission finds most of the money for annual maintenance and up to fifty per cent of approved capital expenditure, the institutions having to find the remainder.

The Development Commission spends its money wisely, but it is not the only body financing agricultural research. The Land Fertility Committee, the Sugar Commission, the various marketing boards all spend or can spend money under this name. In this awakening interest in agriculture, history is repeating itself: "The farming tribe", wrote Arthur Young a hundred and fifty years ago, "is now made up of all ranks, from a duke to an apprentice". So the promoters of agricultural research are in our time widespread and numerous. Unfortunately, apart from the Sugar Commission, the so-called research is not infrequently not research at all, and indeed the effect of one of these bodies has been to put an end to some work of permanent value that was being done. Happily, the Agricultural Research Council is getting into its stride, and when it is fully functioning it will prevent some of the wastage still liable to occur.

\section{INTEGRATION IN THE CENTRAL NERVOUS SYSTEM}

The Form and Functions of the Central Nervous System

An Introduction to the Study of Nervous Diseases. By Prof. Frederick Tilney and Prof. Henry Alsop Riley. Third edition. Pp. xxxvii +851 . (London: H. K. Lewis and Co. Ltd., 1938.) 50s. net.

$\mathrm{N}$ no part of the body is the relation of form 1 and function so clear as in the central nervous system. Modern neurology owes its present position to advances in knowledge which have come from many sources. Comparative anatomy has shown clearly how the brain has altered and increased in size with the gradual evolution of the mammalian scries, and the addition of new centres to the primitive brain can usually be correlated with changes in the habits or reactions of the new species. Anatomists havo aided in the understanding of the human brain by two further lines of approach. Embryological investigation has helped in outlining the various components of the brain and, by a study of the gradual myelinization of tracts, has correlated structure with function. Finally, histological investigations have shown that different parts of the nervous system contain highly differentiated cells, and cortical areas outlined by histological means have been found to subserve different activities. On the other hand, detailed study of the functions of the central nervous system has helped, in many instances, to a clearer understanding of the structure-study based both on physiological experiment and on elinical observation of patients with organic nervous disease.
Profs. Tilney and Riley, in their book, founded on a clear understanding of this important relation of form and function in the nervous system, have provided a model for a text-book, a model which might well be copied for other systems in the body. Physiology and anatomy used to be regarded by students as two widely separated subjects. This book provides detailed anatomical and histological descriptions of the various component parts of the nervous system, associated in each instance with an account of the erolutionary and embryo. logical significance of that part and followed by an account of its function, based partly on physiological principles, but illustrated by clinical syndromes. Case reports, used throughout the book, indicate to the student how dependent diagnosis is on a knowledge of detail, and serve as an excellent introduction to the study of neurology.

To a clear account of the spinal cord and the simple reflex arc, the authors gradually add details of the higher structures of the primate nervous system, and the increasing complexity of the control of the simple reflex, by the addition of new association tracts, both sensory and motor, is easy to follow. The development of the cerebellum and its function in the 'synergic regulation of muscular patterns' is particularly well described.

Perhaps the most interesting sections of the book are those dealing with tho cerebral cortex. The evolution of the cerebral hemispheres is seen in its highest form in the human brain, and, following a full account of the cortical localization of both 